\title{
SÚLYOS, FERTŐZÉSES EREDETŰ CSONTELVÁLTOZÁS ELŐFORDULÁSA A KR. E. 6. ÉVEZRED UTOLSÓ HARMADÁBAN VERSEND-GILENCSA LELÖHELYÉN
}

\author{
Köhler Kitti ${ }^{1}$, Voicsek Vanda ${ }^{2}$, Jakucs János $^{1}$ és Pap Ildikó ${ }^{3}$ \\ ${ }^{1}$ Magyar Tudományos Akadémia, Bölcsészettudományi Kutatóközpont, Régészeti Intézet, \\ Budapest; ${ }^{2}$ Budapest; ${ }^{3}$ Magyar Természettudományi Múzeum, Embertani Tár, Budapest
}

Köhler K., Voicsek V., Jakucs J., Pap I.: The presence of severe skeletal infection on the human remains of a Middle Neolithic Sopot culture, excavated at Versend-Gilencsa. This article presents a new skeletal infection from the Middle Neolithic (Sopot culture) in the Carpathian Basin from the site of Versend-Gilencsa (6th millennium BC). The site yielded 27 burials from this period. During the biological anthropological and paleopathological examinations, the skeletal remains of an adult male (Grave 1078) displayed lesions: severe cavitation, collapse of vertebrae, hypervascularisation, inflammation on the sternum and periostitis on the long bones. Based on these alterations, the presence of atypical spinal tuberculosis or brucellos infection may be assumed in the community of Versend. The planned paleomicrobiological investigation may confirm the presumed diagnosis.

Keywords: Carpathian Basin; Versend-Gilencsa; Middle Neolithic Age; Sopot culture; Paleopathology; Skeletal infection; Tuberculosis; Brucellosis.

\section{Bevezetés}

Az elmúlt tíz évben lezajlott nagyberuházások - elsősorban az M6-os autópálya építését megelőző feltárások - során több, a Kr. e. 6. évezred utolsó harmadára keltezhető középső neolitikus településnyom került elő a Dunántúl délkeleti régiójában. Ezeken a településeken belül számos temetkezés is napvilágot látott. Az M6-os autópálya nyomvonal Baranya megyei szakaszán Versend-Gilencsa (M6B096) lelöhelyen 2006 és 2007 között a Janus Pannonius Múzeum munkatársai végeztek leletmentő ásatást. A Versendi-vízfolyás két partján húzódó lelőhelyen más korszakok (Lengyeli kultúra, Baden-kultúra, La-Téne kultúra, Római kor, Avar kor) emlékei mellett, a középső neolitikum időszakára keltezhető épületnyomok és 27 temetkezés került elő (Jakucs és mtsai 2016b).

A közelmúlt régészeti kutatásai rámutattak, hogy a Dunántúl délkeleti, Duna menti régiója a tárgyalt korszakban a közép-európai és balkáni újkökori közösségek érintkezési zónájába tartozott (Marton és Oross 2012, Jakucs és mtsai 2016a). A Dél-Baranyaidombság területén található középső neolitikus településeken, így Versend-Gilencsán és a tőle néhány kilométerre nyugatra található Szederkény-Kukorica-dűlőn elsősorban már nem a közép-európai vonaldíszes, hanem sokkal inkább az észak-balkáni Vinča és korai Sopot típusú tárgyi kultúra hatása érvényesült (Jakucs és Voicsek 2015, Jakucs és mtsai 2016a, b). A tanulmányban tárgyalt 1078. számú temetkezés a lelőhely nyugati részén, egy nagyméretủ újkőkori gödör együttes szélénél látott napvilágot. A Ny-K-i tájolású, jobb oldalán zsugorított testhelyzetben fekvő csontváz mellől sírmelléklet nem került elő 
(1. ábra). A gödörből, amelybe a sírt beleásták, mostanáig csak korai Vinča stílusú kerámia leletanyagot ismerünk. Azonban a csontvázból vett radiokarbon minta adata alapján (Kr. e. 5000-4910 kal., 68,2\% valószínüség; Kr. e. 5025-4845 kal., 95,4\% valószínűség) a temetkezés a település későbbi, a középső neolitikum legvégére keltezhető periódusába tartozik, és valószínűleg a Sopot kultúrával hozható összefüggésbe.

A kóros elváltozások vizsgálata során egy egyén csontmaradványain súlyos morfológiai elváltozásokat figyeltünk meg. Ezek leírását, paleopatológiai elemzését és az eredményekkel kapcsolatos diszkussziót kívánjuk jelen tanulmányunkban bemutatni.

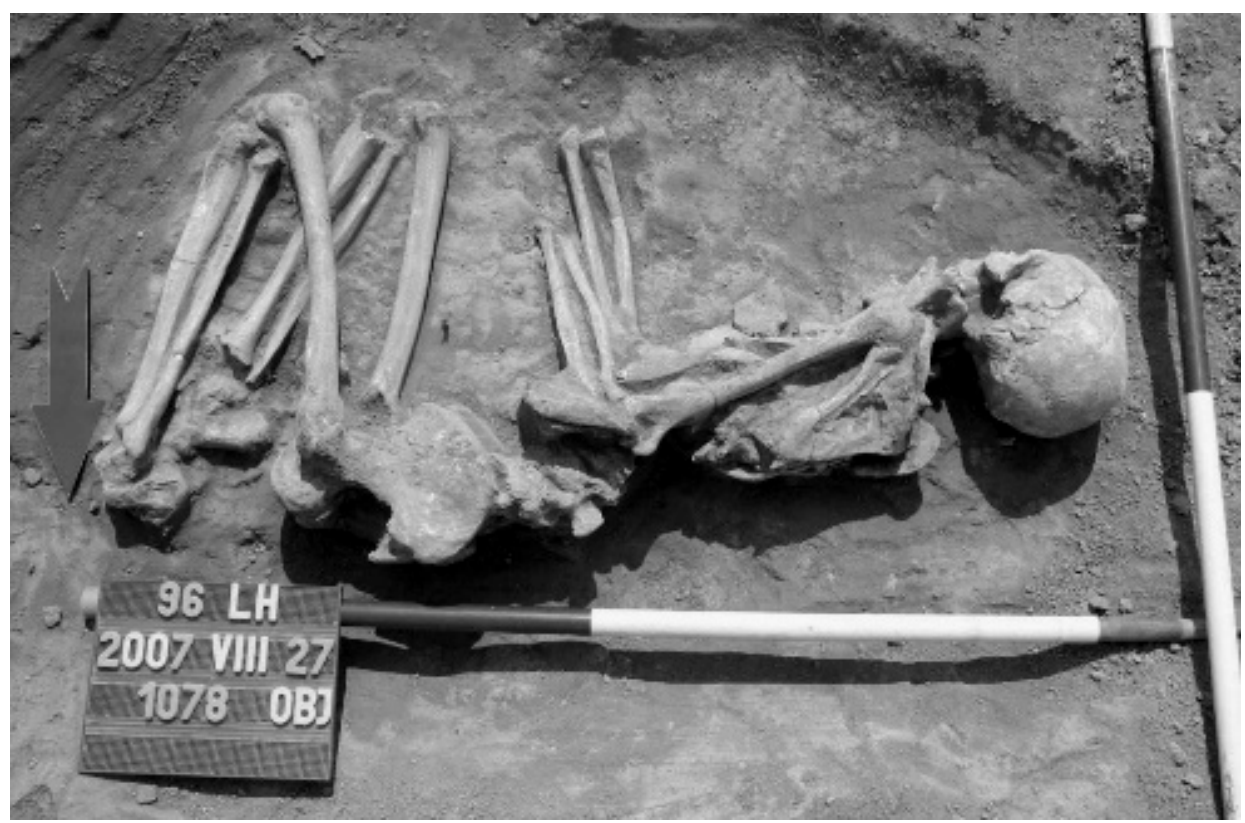

1. ábra: Az 1078-as temetkezés. Versend-Gilencsa.

Fig. 1: Burial No. 1078. Versend-Gilencsa.

\section{Anyag és módszer}

A leletek hagyományos antropológiai feldolgozását K. Zoffmann Zsuzsanna végezte el. Az eltemetettek nemének meghatározása a koponyán és a vázon megfigyelt metrikus és morfológiai jegyek alapján történt (Éry és mtsai 1963). Az elhalálozási életkor becslése során gyermekeknél a tej- és a maradó fogak kibúvási rendjén, illetve fejlettségi fokán (Schour és Massler 1941, Ubelaker 1989), valamint a végtagcsontok hosszán alapuló módszereket (Stloukal és Hanáková 1978) használta. Juvenis korcsoportúaknál az epiphysisporcok elcsontosodási mértékét vizsgálta (Ferembach és mtsai 1979). Felnőtteknél a szeméremcsont facies symphysialis-án mutatkozó életkori változásait, (Todd 1920), az agykoponya varratainak külső és belső felszíni elcsontosodását (Nemeskéri és mtsai 1960, Meindl és Lovejoy 1985), valamint a fogak kopásának mértékét (Miles 1963, Perizonius 1981) vette figyelembe. 
A humán leletanyag összességében közepes megtartású, de a lelőhelyen olyan töredékes maradványok is előfordultak, amelyek alkalmatlanok voltak a klasszikus embertani vizsgálatra.

K. Zoffmann Zsuzsanna a lelőhelyről feltárt 27 egyén közül 24 vizsgálatát végezte el. 7 férfi, 9 nő, 3 nem meghatározható nemü (illetve 1 nőként meghatározott juvenis korú egyén), továbbá 1 infans I. és 3 infans II. korú gyermek maradványait különítette el.

A leletanyag paleopatológiai vizsgálatára K. Zoffmann Zsuzsanna az MTA Régészeti Intézetének munkatársait kérte fel. A patológiás elváltozások makroszkópos vizsgálata során Steinbock (1976), Aufderheide és Rodriguez-Martin (1998), Ortner (2003) munkáit használtuk fel. Az atípusos tuberkulózis felismeréséhez Pálfi és mtsai (1999, 2011), Maczel (2003), Hershkovitz és mtsai (2002, 2008) munkái, a brucellosis elemzéséhez Mutolo és mtsai (2012), valamint Mays és mtsai (2001), Mays és Taylor (2003) publikációi szolgáltak útmutatóul.

A leletanyag a feldolgozás után a pécsi Janus Pannonius Múzeumba került vissza.

\section{Vizsgálati eredmények}

Az 1078-as sírban fekvő adultus korú férfi koponyája, alsó állcsontja és vázrészei egyaránt töredékesek, hiányosak. A csontmaradványok paleopatológiai elemzése során a postcranialis vázrészleten több kóros elváltozást is sikerült megfigyelni.

Koponya. A belső felszín vízköves. A koponya fal- és nyakszirti részén enyhe poroticus hyperostosis figyelhetö meg.

Csigolyák. A gerincből 1 nyaki (C7), 5 háti (Th4-6, Th10-11) és 4 ágyéki (L2-5) csigolya maradt meg.

A vázmaradványok többsége töredékes, hiányos, vízkővel fedett.

A következökben részletes leírással mutatjuk be a vázon megfigyelt patológiás elváltozásokat.

Gerincoszlop nyaki szakasza. A 7. nyakcsigolya jobb processus articularis superior-án kismértékü ízületi gyulladás jött létre.

Gerincoszlop háti szakasza. A 4. háti csigolya testének felső és alsó felszíne porotikus. A cranialis felszín középső részén bemaródás látható. A test oldalán hypervascularisatio. A csigolyaív hiányzik. Az 5. háti csigolya testének superior felszíne kismértékben porotikus. A csigolyatest oldalán hypervascularisatio. A csigolyaív hiányzik. A 6. háti csigolya testének felső és alsó felszíne is kismértékben porotikus. A test mindkét oldalán hypervascularisatio. A 10. háti csigolya teste töredékes, hiányos, csigolyaív nincs. A test alsó felszíne porotikus és rajta üregképződés figyelhető meg. A 11. háti csigolya testének superior és inferior felszíne is kismértékben porotikus. A csigolyatest bal oldalán gyulladás nyomai figyelhetők meg. A test jobb oldalának felső részén jelentős osteophyta képződés alakult ki (2. ábra).

Gerincoszlop ágyéki szakasza. A 2. ágyéki csigolya testének superior felszíne kismértékben porotikus. Inferior irányból jelentős méretủ bemaródás, csontpusztulás, közepes mértékủ magasságvesztés figyelhető meg. A csigolyatest bal oldalán periostealis appositio (3. ábra) nyomai látszódnak. A 3. ágyéki csigolya teste kismértékben töredékes. Felső felszínén jelentős üregképződés, alsó felszínén gyulladás nyomai figyelhetők meg. A corpus jelentős magasságvesztése (4. ábra). A töredékes 4. ágyéki csigolya testének superior felszíne porotikus, inferior felszínén jelentős üregképződés, gyulladás nyomai látszódnak. A bal felső kisízület gyulladt. Közepes mértékủ magasságvesztés (5. ábra) a 
4. ágyékcsigolyán. A kismértékben hiányos 5. ágyéki csigolya testének felső felszíne porotikus, elülső oldalán kismértékü bemaródások, a test peremén osteophyta képződés figyelhető meg. Az alsó felszínen két nagyobb üreg képződött. Mindez a test enyhe magasságvesztését okozta. Az 1-4-ig terjedő csigolyaívek összecsontosodtak, ventralis oldalukon gyulladás nyomai (6. ábra).

Medencetájék. Mindkét medencelapát hiányos, felszínükön kóros elváltozás nem látható. A töredékes, hiányos keresztcsonton nem mutatkozik betegségre utaló elváltozás.

Bordák. A bordákon semmilyen kóros elváltozás nem látható.

Szegycsont. A manubrium sterni dorsalis felszínén jelentős, ventralis felszínén kismértékü gyulladás (7. ábra) látható.

Hosszú csontok. Mindkét oldali femur proximalis részén ventralisan, a linea pectinea és a tuberositas glutea között jelentős, mindkét tibia diaphysisén kismértékü periostealis appositio jött létre. A nagyízületeken elváltozás nincs. A jobb könyökízületben kismértékü arthrosis deformans figyelhető meg.

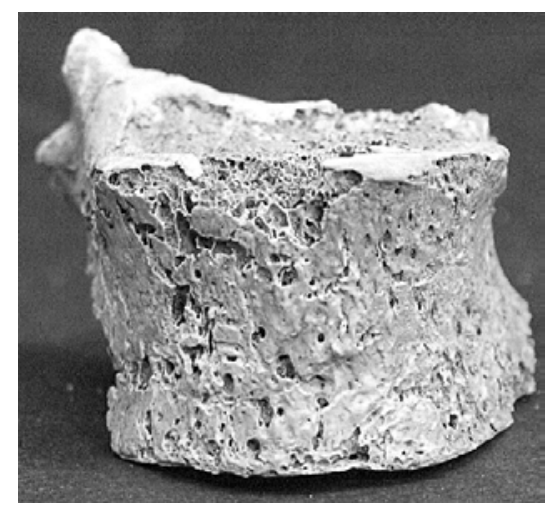

2. ábra: Hypervascularisatio a 11. hátcsigolyán (1078. sír).

Fig. 2: Hypervascularisation on the 11th thoracal vertebra (Grave No. 1078).

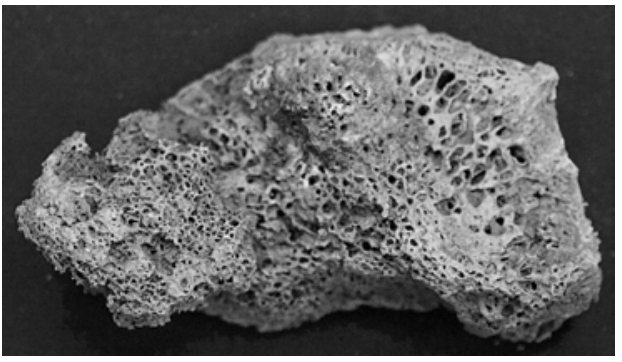

a

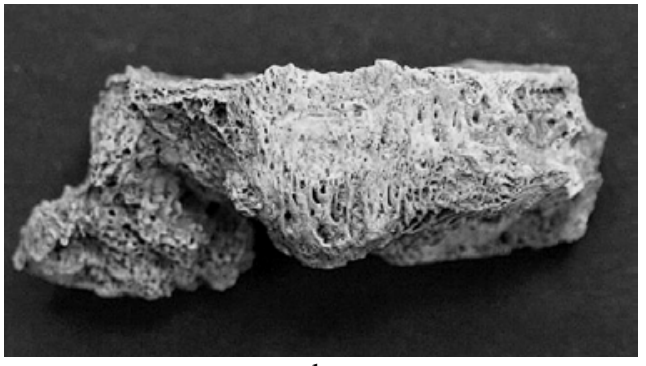

b

3. ábra: A 2. ágyékcsigolya (a) caudalis felszínén jelentős csontpusztulás, (b) corpus-ának oldalán periostealis appositio (1078. sír).

Fig. 3: (a) Severe bone destruction, (b) peristeal apposition on side of the the 2nd lumbar vertebra (Grave No. 1078). 


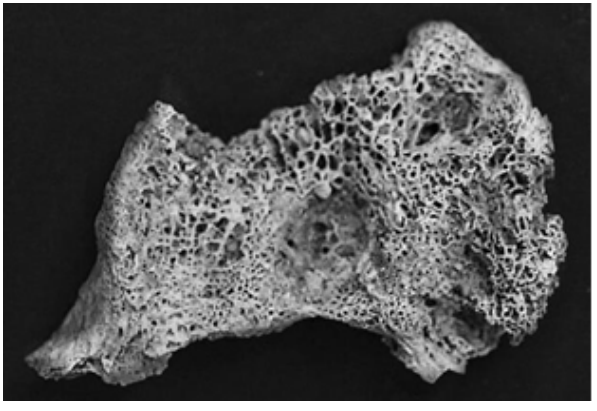

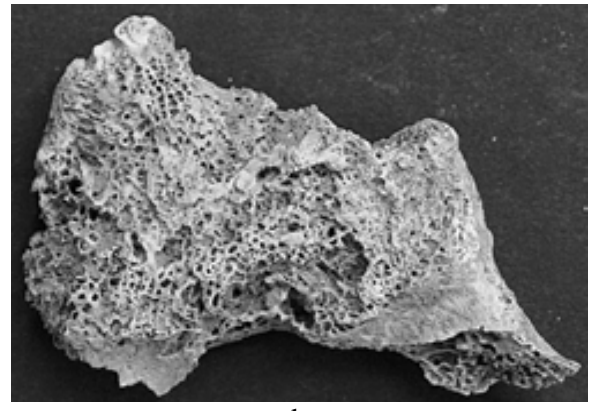

b

4. ábra: (a) Üregképződés és jelentős mértékü destrukció (cranialis felszínen), (b) csontpusztulás és gyulladás (caudalis felszínen) a 3. ágyékcsigolyán (1078. sír).

Fig. 4: (a) Cavitation and severe destruction on the cranial face, (b) bone destruction and inflammation on the upper part of the 3rd lumbar vertebra (Grave No. 1078).

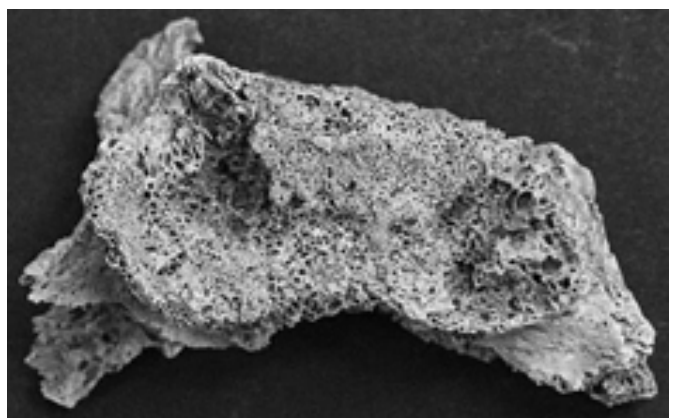

5. ábra: A 4. ágyékcsigolya testének caudalis felszínén üregképződés és csontpusztulás (1078. sír). Fig. 5: Cavitation and bone destruction on the lower part of the 4th lumbar vertebra (Grave No. 1078).
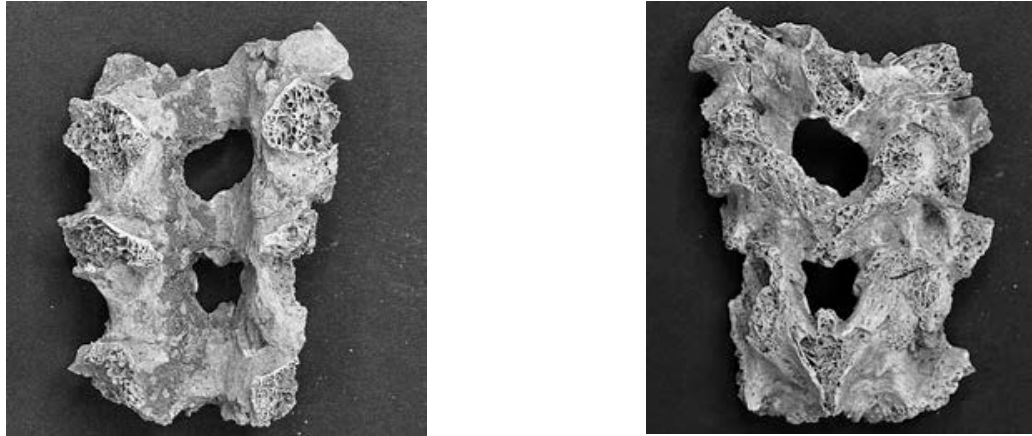

6. ábra: Az ágyéki csigolyaívek összecsontosodása. (a) Ventralis nézet, (b) dorsalis nézet (1078. sír). Fig. 6: Synostosis of the lumbar arches. (a) Ventral view, (b) dorsal view (Grave No. 1078).

Egyéb elváltozások. Mindkét sarokcsonton közepes mértékü enthesopathia figyelhető meg. Az állkapocs frontfogain fogkőképződés, a jobb felső második metsző fogon és a szemfogon hypoplasia, az állkapocs frontfogainak külső oldalán fogkőképződés látható. 


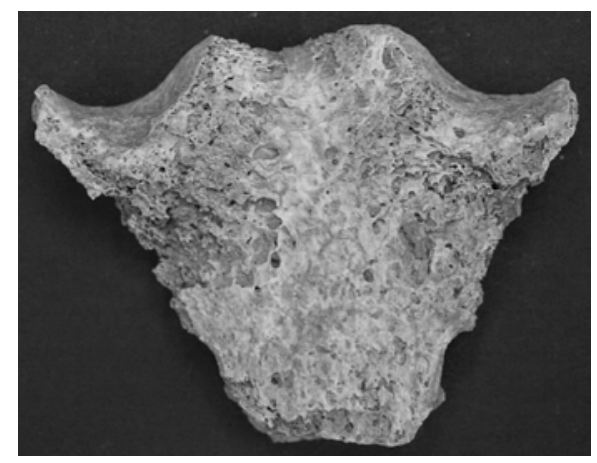

7. ábra: Gyulladás nyomai a manubrium sterni felszínén (1078. sír).

Fig. 8: Traces of inflammation on the manubrium sterni (Grave No. 1078).

\section{Differenciáldiagnózis}

A Versend-Gilencsa lelőhely 1078. számú sírjából származó férfi csontmaradványain észlelt elváltozások (a csigolyák feszínén lévő hypervascularisatio és a hosszú csontokon megmutatkozó periostitis) az úgynevezett atipikus vagy korai fázisú tuberkulózisra utalnak. Bár valószínüsíthetö pozitív összefüggés ezek között az elváltozások és a tbc között, ezek nem specifikusak a tuberkulózisra. Más megbetegedések is okozhatnak hasonló elváltozásokat, de együttes előfordulásuk megerősítheti az ún. korai fázisú (earlystage) tuberkulózis (Pálfi 2002, Maczel 2003) diagnózisát.

Az elörehaladott csontízületi tuberkulózis jellegzetes nyomai általában egyszerü inspekciós módszerrel is könnyen felismerhetők. „Klasszikus” tünetei leggyakrabban a csigolyákon, általában a gerinc alsó, háti és ágyéki szakaszán jelennek meg, az ún. spondylitis tuberculosa formájában. A betegség következménye a szivacsos állomány destrukciója, végső soron a csont összeroppanása és az ún. Pott-féle gibbus kialakulása. A destruktív léziók mellett az eredeti csontállomány átépülése és újcsontképződés megjelenése is előfordulhat. A léziók alapvetően a csigolyatesteket érintik, azaz a csigolyaívekre és a harántnyúlványokra csak ritkán terjednek át (Kelley és El-Najjar 1980, Resnick és Niwayama 1988, Aufderheide és Rodríguez-Martin 1998, Ortner 2003, Maczel 2003). Ízületbeli előfordulása (csípö- és térdízület) is gyakori. Előfordulhat a süllyedéses tályog (abscessus psoilicus). Coxitis tuberculosa esetén a góc a fovea capitis környékén, a femur nyaki részén vagy az acetabulumban van.

A versendi esetnél nem fordult elö sem a gerincoszlop jellegzetes súlyos gibbusa, sem csípőizületi elváltozás, sem tályog, ugyanakkor több csigolya testén is elöfordult olyan jellegzetes üregképződés (3-4. ábra), amelyeket korábban egyértelmüen, archaeogenetikai elemzésekkel is bizonyítottan társítottak csonttuberkulózishoz (Évinger és mtsai 2011, Hajdu és mtsai 2012).

Számos hazai és nemzetközi szerző foglalkozott azzal a problematikával, hogy az elörehaladott állapotra jellemző tünetek alapján a diagnózis biztos lehet, ugyanakkor, ha a betegség még csak a kezdeti stádiumban tart, akkor annak felismerése nehézségekbe ütközhet. Azaz, ha csak a klasszikus csonttani tüneteket vesszük figyelembe, akkor nagymértékben alábecsülhetjük a tuberkulózis előfordulási gyakoriságát. Ezt a problémát felismerve, egyre több tanulmány jelent meg olyan morfológiai elváltozások megjelenésével kapcsolatban, amelyek ismert halálozási okú egyének 
csontvázmaradványainak vizsgálata alapján összefüggésbe hozhatók a tuberkulózissal (atipikus csonttani tünetek: endocraniális elváltozások, borda léziók, csigolyatestek hypervascularizációja, stb.). Emellett bizonyos fertőzésekhez kapcsolódó, korábban „stressz indikátor” kategóriába sorolt tünetek is (cribra obitalia, cribra cranii, periostitis a hosszú csontokon) számításba jöhetnek (Kelley és Micozzi 1984, Haas és mtsai 1999, 2000, Schultz 1999, Santos és Roberts 2001, Hershkovitz és mtsai 2002, Maczel 2003, Matos és Santos 2006, Pálfi és mtsai 2011).

A tbc-re jellemzö atipikus elváltozások közül esetünkben a koponyacsontok belső felszíne a vízkövesedés miatt nem volt vizsgálható, de felnőttek, és föleg maturus korú egyének esetében az endocranialis léziók megléte egyébként is ritkább, mint a felnőttkort el nem érők esetében. A bordákon lézió szintén nem fordult elő, a hosszú csontokon periostealis felrakódást észleltünk.

A megfigyelt elváltozásokkal kapcsolatban ugyanakkor teljes biztonsággal nem zárható ki a brucellózis fertőzésének lehetősége sem, amelyet a Brucella baktériumtörzs különböző kórokozói váltanak ki. Ez a kórokozó elsősorban az ágyéki csigolyákban telepszik meg, ahol ún. gócokat képez. A brucellózis második szakaszában az ízületek és csigolyák környékén okozhat lytikus léziókat, csont-destrukciók formájában. A csonttömeg fogyása kismértékủ csontritkulás (osteoporosis) formájában jelentkezik, a betegség elörehaladott állapotában pedig csigolya spondylitis-t vagy a hosszú csontok osteomyelitis-ét okozhatja. Mivel a tbc is ezekben a régiókban okoz elváltozásokat, a két betegség elkülönítő diagnózisa nehézségeket okozhat (Mays 2008). Talán az egyetlen biztos eredményt a DNS vizsgálatok adhatnak (Mutolo és mtsai 2012).

A primer és szekunder tumorok is okozhatnak a csigolyákon elváltozást. A csigolyákat is érintő ráktípus, pl. a primer, rosszindulatú myeloma multiplex, mely a csontvelöi plazmasejtek tumoros megbetegedése. Ez a daganattípus áttétet képez a medencén, a bordákon, a csigolyákon, több, általában kerek vagy ovális osteolytikus elváltozást, gócos destrukciót okozva. Ugyanígy más szervekböl kiinduló tumorok is okozhatnak csonttani tüneteket a csigolyákon. Tekintettel arra, hogy a versendi újkőkori egyén csigolyáin, bordáin, medencecsontjain sem primer, sem metasztatikus jellegzetes elváltozás (Greenspan és Remagen 1998) nem volt, ezért a tumor lehetösége ebben az esetben véleményünk szerint elvethetö.

A fentieket összegezve a versendi újkőkori egyén szervezetében egy súlyos fertőzés lehetett jelen, és a legvalószínübb diagnózisnak a csonttuberkulózis tünik, ugyanakkor a brucellózis sem zárható ki. Az eset biztos diagnosztizálásához a későbbiekben radiológiai és paleomikrobiológiai vizsgálatok elvégzése szükséges.

\section{Vizsgálati eredmények megtárgyalása és következtetések}

A brucellózis elterjedése a humán népességben meglehetősen ritka (Glasgow 1976), jelenléte függ a szarvasmarha, ló, kecske, birka, kutya domesztikációjának mértékétől.

A megbetegedést leíró paleopatológiai publikációk száma meglehetősen ritka. Brothwell (1965) a Közel-Keletről származó bronzkori esetről, Capasso (1999) Herculaneum területéről számol be a betegség jelenlétéről. Ortner monográfiája összegzi az addig leírt előfordulásait (2003). A téma legújabb összefoglalója Wright (2016) munkája, amelyben nem csak a morfológiai eltéréseket írja le részletesen, hanem a genetikai vizsgálatok eredményeit is. Ugyanebben a munkában kitér a tuberkulózisra is. 
A gümőkór vagy tuberkulózis (tbc) az egyik legrégibb specifikus fertőző megbetegedés, amelyet a Mycobacterium tuberculosis complex-be (MTBC) tartozó baktériumok okoznak (Donoghue 2009).

A betegség nyomait mutató legrégebbi (kb. 9000 éves) csontvázleletek a Közel-Kelet preneolitikus időszakából Irak (Ortner 1999), Jordánia (El-Najjar és mtsai 1997) és Izrael területéről (Hershkovitz és mtsai 2008) ismertek. A legújabb leírás a térségből Dja'de el Mughara and Tell Aswad lelőhelyéről származik (Szíria, Kr. e. 8800-8300 kal. és Kr. e. 8200-7600 kal.); Baker és munkatársai (2016) öt egyén esetében mutattak ki tuberkulózist. Tekintettel arra, hogy a leletek a PPNB korából, azaz a háziasítás, állattartás, növénytermesztést megelőző periódusból származnak, megdőlt az az elmélet, amely szerint a neolitizáció eredményezte a kétféle Mycobacteriális fertőzést. További, bár vitatott esetek ismertek a Közel-Kelet rézkori és kora bronzkori periódusaiból a jordániai Bab-edh-Dhra' (Ortner 1979) és az izraeli Wadi Makuq (Zias 1998) lelőhelyekröl.

Több ezer éves egyiptomi múmiákat vizsgálva számos esetben diagnosztizálták a fertőzés nyomait, bizonyítva, hogy a kór a pre-dinasztikus egyiptomi társadalmat sem kímélte (Strouhal 1987, Crubézy és mtsai 1998).

Európában sokáig a legrégibbnek (kb. 5000 éves) tekintett lelet a németországi Heidelberg lelőhelyről került elő (Bartels 1907), de további újkőkori eseteket ismerünk az itáliai Arena Candide barlangból (Formicola és mtsai 1987), a franciaországi Loisy-en Brie közeléből (Dastugue és de Lumpley 1976), Lengyelországból (GladykowskaRzeczycka 1999), Svédországból (Nuorala és mtsai 2004), Dániából (Sager és mtsai 1972, Bennike 1985, 1999) és az angliai vaskori Dorset településröl (Mays és Taylor 2003). Legújabban a németországi közép-európai vonaldíszes kultúra lelőhelyein írtak le három esetet, amelyek közül két egyén testén a klasszikus, Pott-féle púp volt megfigyelhetö, további egy egyén maradványain a betegségre jellemző atipikus tünetek mutatkoztak (Nicklisch 2012).

Az utóbbi években a Kárpát-medencei neolitikum időszakából is egyre több tbc-s elváltozást közöltek a kutatók. Ezek többsége a kései neolitikumból származik, de már a középső, sőt a korai újkőkorból is ismertek esetleírások (8. ábra). Az eddig publikált legrégibb, feltételezett tbc-s leletek az Alsónyék-Bátaszéken feltárt, a korai neolitikus Starčevo kultúrához tartozó temetkezések esetében ismertek. A lelőhelyről 3 egyén esetében merült fel a fertőzés gyanúja a morfológiai elváltozások alapján (Köhler 2015).

A késő neolitikus alföldi Tiszai kultúra (Kr.e. 5000/4900-4500/4400) Hódmezővásárhely-Gorzsa lelőhelyéről ismerünk tbc-vel fertőzött egyéneket, ahol öt csontváz makroszkópos morfológiai jegyeiket tekintve atipikus, a megbetegedés korai stádiumára utaló tüneteket mutat. A feltételezett tbc-re utaló megbetegedések pontosabb diagnózisának megállapítására molekuláris biológiai módszerek alkalmazására is sor került. A lipid biomarker analízis mind az öt esetben, míg az aDNS három esetben hozott pozitív eredményt (Masson és mtsai 2008, 2013, 2015, Masson 2011).

Az ugyancsak a Tiszai kultúrához sorolható Vésztö-Mágor lelőhelyről négy feltételezett tbc-s esetet írtak le. A tünetek egy egyénen multifokális tuberkulózisra, három esetben atípusos, vagy korai stádiumú tbc-re utalnak. A makromorfológiai alapon felállított diagnózist ebben az esetben is molekuláris biológiai vizsgálatokkal egészítették ki, amely egy esetben, éppen az egyik atípusos tüneteket mutató egyénnél mutatta ki a mycobacterialis DNS jelenlétét (Spekker és mtsai 2013). 
A késő neolitikus dunántúli Lengyeli kultúrából (4900/4800-4500/4400) ismert esetek Alsónyék-Bátaszékről származnak. Ebben a szériában a tbc-re jellemző „klasszikus” elváltozások (Pott-féle megbetegedés) egy férfi gerincoszlopán voltak megfigyelhetők (Köhler és mtsai 2013a, b, 2014). A csontmaradványokból nyert radiokarbon eredmények alapján az embertani lelet kora: Kr. e. 4700-4655 kal. (68\% valószínüség), Kr. e. 4720-4605 kal. (95\% valószínúség). Tekintettel arra, hogy egyes feltételezések szerint a Lengyeli közösség a halottait vérségi alapon szerveződő sírcsoportokba temette, a későbbiekben megtörtént a férfivel közös sírcsoportba temetett összes egyén paleomikrobiológiai vizsgálata. Ennek eredményeként további 4 esetben sikerült egyértelmüen igazolni a tbc-s fertőzöttség meglétét (Pósa és mtsai 2015).

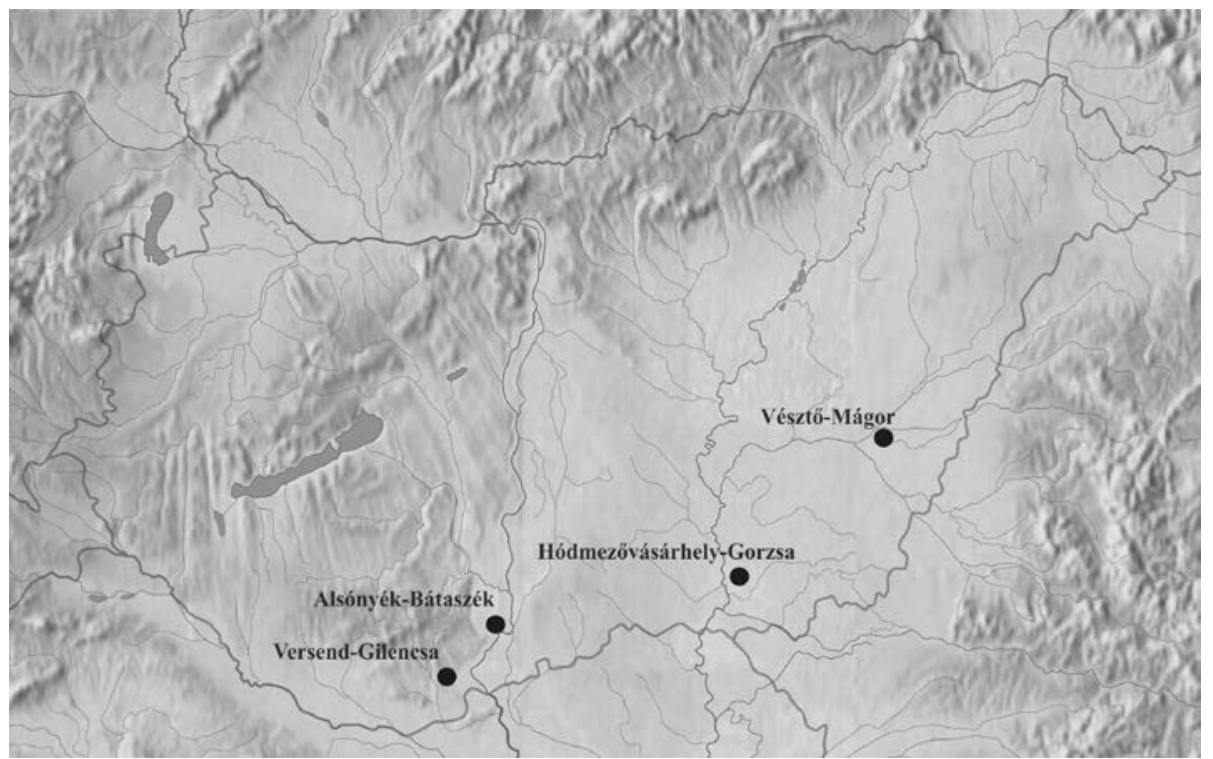

8. ábra: Kárpát-medencei publikált tbs-s esetek.

Fig. 8: Published TB cases from the Carpathian Basin.

A későbbi időszakokból származó leletek paleopatológiai elemzése azt támasztja alá, hogy a gümőkór a római és az Árpád-kori népességekben is jelen volt Magyarországon (Marcsik és mtsai 2006, Évinger és mtsai 2011, Hajdu és mtsai 2012).

Az egyre szaporodó korai esetek némiképp módosítják a tbc-s fertőzés, illetve annak járványszerü megjelenésének hipotézisét. Nem olyan régen még a kései neolitikum népességrobbanásához és az ebből fakadó települési koncentrációhoz, az emberi közösségek szoros egymás mellett éléséhez kötötték a megbetegedés megjelenését (Lengyeli kultúra, Tiszai kultúra). Az ennél korábbi esetek azonban ezt az elméletet némiképp árnyalják, azaz nem feltétlenül csak az ún. népességrobbanáshoz, hanem a termelőgazdálkodás megjelenéséhez és a szarvasmarhafélék tej- és hústermékének fogyasztásához is köthető a megbetegedés humán közösségekben történő megjelenése (Cohen és Armelagos 1984).

A bemutatott középső neolit kori versendi eset véleményünk szerint a tuberkulózis jelenlétére utal a versendi közösségen belül, amely jól beleilleszkedik az eddig ismert 
hazai és nemzetközi vonalba, és bővítheti a korai tuberkulózisos esetek számát, továbbá pontosíthatja terjedésének, időbeni megjelenésének időpontját és helyét. Emellett nem zártuk ki a brucellózis jelenlétét sem. Mindennek eldöntésére a későbbiekben a paloeomikrobiológiai vizsgálatok adhatnak választ. Véleményünk szerint, ha a tbc jelenléte igazolódik, az is az egyik legkorábbi esetek közé tartozik. Ugyanakkor, ha az elváltozás a brucellózis jelenlétét igazolja, akkor a betegség esetében a versendi lelet egyértelmúen a legkorábbi eset.

\section{A tanulmányt Dr. K. Zoffmann Zsuzsanna emlékének ajánljuk.}

Köszönetnyilvánítás: Hálásan köszönjük Hajdu Tamásnak és a kézirat lektorainak a tanulmány elkészítése során nyújtott szakmai tanácsaikat és észrevételeiket.

\section{Irodalom}

Aufderheide, A.C., Rodriguez-Martín, C.R. (1998): The Cambridge Encyclopedia of Human Paleopathology. Cambridge University Press, Cambridge.

Baker, O., Lee, O.Y, Wu, H.H., Besra, G.S., Minnikin, D.E., Llewellyn, G., Williams, C.M., Maixner, F, O’Sullivan, N., Zink, A., Chamel, B., Khawam, R., Coqueugniot, E., Helmer, D., Le Mort, F., Perrin, P., Gourichon, L., Dutailly, B., Pálfi, Gy. (2016): Human domestication predates in ancent Síria. Tuberculosis, 95(Suppl 1): S4-S12. DOI: 10.1016/j.tube.2015.02.001

Bartels, P. (1907): Tuberkulose (Wirbelkaries) in der jüngeren Steinzeit.

Bennike, P. (1985): Stenalderbefolkningen pa oerne syd for Fyn. In: Skaarup, J. (Ed.) Yngre Stenalder pa oerne syd for Fyn. Rudkobing, Langelands Museum, Danmark. pp. 467-491.

Bennike, P. (1999): Facts or myths? A re-evaluation of cases of diagnosed tuberculosis in Denmark. In: Pálfi, Gy., Dutour, O., Deák, J., Hutás, I. (Eds) Tuberculosis. Past and present. Golden Book Publishers and Tuberculosis Foundation. Budapest-Szeged. pp. 511-518.

Brothwell, D. R. (1965): Digging up Bones. British Museum. London.

Capasso, L. (1999): Brucellosis at Herculaneum (79 AD). International Journal of Osteoarchaeology, 9:277-88.

Cohen, M.N., Armelagos, G.J. (1984): Paleopathology at the Origins of Agriculture: Editors'summation. In: Cohen, M.N., Armelagos, G.J. (Eds) Paleopathology at the Origins of Agriculture. Academis Press, New York. pp. 585-601.

Crubézy, E., Ludes, B., Poveda, J.D., Clayton, J., Crouau-Roy, B., Montagnon, D. (1998): Identification of Mycobacterium DNA in an Egyptian Pott's disease of 5400 years old. Comptes Rendus de l'Academie des Sciences, 321: 941-951. DOI: http://dx.doi.org/10.1016/S0764-4469(99)80009-2

Dastugue, J., de Lumley, M.A. (1976): Les maladies des hommes préhistoriques. In: Guilaine, J. (Ed.) La prehistorie française, Tome II. Les civilisations néolithiques et protohistoriques de la France. CNRS, Paris. pp. 153-164.

Donoghue, H.D (2009): Human tuberculosis - an ancient disease, as elucidated by ancien microbial biomolecules. Microbes and Infection, 11: 1156-1162. DOI: 10.1016/j.micinf.2009.08.008

El-Najjar, M., Al-Shiyab, A., Al-Sarie, I. (1997): Cases of tuberculosis at 'Ain Ghazal, Jordan. Paléorient, 22(2): 123-128.

Éry, K., Kralovánszky, A., Nemeskéri, J. (1963): Történeti népességek rekonstrukciójának prezentációja. Anthropologiai Közlemények, 7: 41-90.

Évinger, S., Bernert, Zs., Fóthi, E., Wolff, K., Kővári, I., Marcsik, A., Donoghue, H.D., O'Grady, J, K. Kiss, K., Hajdu, T. (2011): New skeletal tuberculosis cases in past populations from Western Hungary (Transdanubia). HOMO, 62(3): 165-183. DOI: 10.1016/j.jchb.2011.04.001 
Ferembach, D., Schwidetzky, I., Stloukal, M. (1979): Empfehlungen für die Alters- und Geschlchtsdiagnose am Skelett. HOMO, 30: 1-32.

Formicola, V., Milanesi, Q., Scarsini, C. (1987): Evidence of Spinal Tuberculosis at the Beginning of the Fourth Millennium BC from Arene Candide Cave (Liguria, Italy). American Journal of Physical Anthropology, 72(1): 1-6. DOI: 10.1002/ajpa.1330720102

Gladykowska-Rzeczycka, J.J. (1999): Tuberculosis in the past and present in Poland. In: Pálfi, Gy., Dutour., Deák, J., Hutás, I. (Eds) Tuberculosis. Past and present. Golden Book Publishers and Tuberculosis Foundation, Budapest - Szeged. pp. 561-573.

Glasgow, M.M.S. (1976): Brucellosis of the spine. British Journal of Surgery, 63(4): 283-288.

Greenspan, A., Remagen, W. (1998): Differential Diagnosis of Tumors and Tumor-like Lesions of Bone and Joints. Philadelphia, New York, 1998.

Haas, Ch.J., Zink, A., Molnár, E., Marcsik, A., Dutour, O., Nerlich, G.A., Pálfi, Gy. (1999): Molecular evidence for tuberculosis in Hungarian skeletal samples. In Pálfi, Gy., Dutour, O., Deák, J., Hutás, I. (Eds) Tuberculosis Past and Present. Golden Book Publishers and Tuberculosis Foundation, Budapest - Szeged. pp. 385-395.

Haas, Ch.J., Zink, A., Molnár, E., Reischl, U., Marcsik, A., Ardagna, Y., Dutour, O., Pálfi, Gy., Nerlich, A.G. (2000): Molecular evidence for different stages of tuberculosis in ancient bone samples from Hungary. American Journal of Physical Anthropology, 113: 293-304. DOI: 10.1002/1096-8644(200011)113:3<293::AID-AJPA2>3.0.CO;2-6

Hajdu, T., Donoghue, H.D., Bernert, Zs., Fóthi, E., Kővári, I., Marcsik, A. (2012): A case of spinal tuberculosis from the Middle Ages in Transylvania (Romania). Spine, 37(25): E1598-E1601. DOI: $10.1097 /$ BRS.0b013e31827300dc

Hershkovitz, I., Donoghue, H.D., Minnikin, D.E., Besra, G.S., Lee, O., Gernaey, A.M., Galili, C.E., Eshed, V., Greenblatt, C.L., Lemma, E., Kahila Bar-Gal, G., Spigelman, M. (2008): Detection and molecular characterization of 9000-year-old Mycobacterium tuberculosis from a Neolithic settlement in the Eastern Mediterranean. PLoSONE, 3(10): e3426. DOI: 10.1371/journal.pone.0003426

Hershkovitz, I., Greenwald, C.M., Latimer, B., Jellema, L.M., Wish-Baratz, S., Eshed, V., Dutour, O., Rothschild, B.M. (2002) Serpens endocrania symmetrica (SES): a new term and a possible clue for identifying intrathoracic disease in skeletal populations. American Journal of Physical Anthropology, 118: 201-216. DOI: 10.1002/ajpa.10077

Jakucs, J., Bánffy, E., Oross, K., Voicsek, V., Bronk Ramsey, C., Dunbar, E., Kromer, B., Bayliss, A., Hofmann, D., Marshall, P., Whittle, A. (2016a) Between the Vinča and Linearbandkeramik worlds: the diversity of practices and identities in the 54th-53rd centuries cal BC in SouthWest Hungary and beyond. Journal of World Prehistory, DOI: 10.1007/s10963-016-9096-x4

Jakucs, J., Oross, K., Banffy, E., Voicsek, V., Dunbar, E., Reimer, P., Bayliss, A., Marshal, P., Whittle, A. (2016b) Rows with the neighbours: the short lives of longhouses at the Neolithic site of Versend-Gilencsa, Hungary. Közlésre benyújtva.

Jakucs, J., Voicsek, V. (2015): The northermost distribution of the early Vinča Culture int he Danube valley: a preliminary study from Szederkény-Kukorica-dülő (Baranya County, southern Hungary). Antaeus, 33: 13-55.

Kelley, M.A., El-Najjar, M.Y. (1980): Natural variation and differential diagnosis of skeletal changes in tuberculosis. American Journal Physical Anthropology, 52(2): 153-167. DOI: 10.1002/ajpa.1330520202

Köhler, K. (2015): A Starčevo kultúra embertani leletei Alsónyék-Bátaszék lelőhelyről. Anthropologiai Közlemények, 56: 3-26. DOI: 10.20330/AnthropKozl.2015.56.3

Köhler, K., Mende, B.G., Pósa, A. (2013a): A tuberkulózis megjelenése a Dunántúl kései neolitikumában. Magyar Régészet, 2013: 1-5. http://www.magyarregeszet.hu/wpcontent/uploads/2013/07/Kohler_13Ny1.pdf

Köhler, K., Mende, B.G., Pósa, A. (2013b): The emergence of tuberculosis in Late Neolithic Transdanubia. Hungarian Archaeology, 2013. http://www.hungarianarchaeology.hu/wpcontent/uploads/2013/08/eng_Kohler_13ny1.pdf 
Köhler, K., Pálfi, Gy., Molnár, E., Zalai-Gaál, I., Osztás, A., Bánffy, E., Kirinó, K., Kiss, K.K., Mende, B.G. (2014): A Late Neolithic case of Pott's disease from Hungary. International Journal of Osteoarchaeology, 24(6): 697-703. DOI: 10.1002/oa.2254

Maczel, M. (2003): On the traces of tuberculosis” diagnostic criteria of tuberculous affection of the human skeleton and their application in Hungarian and French anthropological series. Phd disszertáció. University of la Méditerranée aix Marseille, Marseille. University of Szeged, Szeged.

Marcsik, A., Molnár, E., Ösz, B. (2006): Specifikus fertőző megbetegedések csontelváltozásai történeti népességek körében. Szegedi Egyetem Kiadó, Szeged.

Marton, T., Oross, K. 2012. Siedlungsforschung in linienbandkeramischen Fundorten in Zentralund Sudtransdanubien - Wiege, Peripherie oder beides? In: Kreienbrink, F., Cladders, M., Stauble, H., Tischendorf, T., Wolfram, S. (Eds) Siedlungsstruktur und Kulturwandel in der Bandkeramik. Landesamt fur Archaologie, Freistaat Sachsen, Dresden. pp. 220-239.

Masson, M. (2011): Tuberculosis at the Late Neolithic Site of Hódmezővsárhely-Gorzsa, Hungary. 13th Annual Conference of the British Association for Biological Anthropology and Osteoarchaeology. Programme and Abstracts, 27-28.

Masson, M., Bereczki, Zs., Molnár, E., Donoghue, H.D., Minnikin, D.E., Lee, O.Y-C., Wu, H.H.T., Besra, G.S., Bull, I.D., Pálfi, Gy. (2015): 7000 year-old tuberculosis cases from Hungary - Osteological and biomolecular evidence. Tuberculosis, 1(Suppl): S13-17. DOI: 10.1016/j.tube.2015.02.007

Masson, M., Molnár, E., Donoghue, H.D, Besra, G.S. Minnikin, D.E., Wu, H.H.T, Lee, O.Y-C., Bull, I.D., Pálfi, Gy. (2013): Osteological and biomolecular evidence of a 7000-year-old case of hypertrophic pulmonary osteopathy secondary to tuberculosis from Neolithic Hungary. PLoSONE, 8(10): e78252. DOI: 10.1371/journal.pone.0078252

Masson, M., Molnár, E., Pálfi, Gy., Bartosiewicz, L. (2008): Palaeopathology of a Neolithic population from Southern Hungary. 17th European Meeting of the Paleopathology Association - Diseases of the Past. Abstracts, 41-42.

Matos, V., Santos, A.L. (2006): On the trail of pulmonary tuberculosis based on rib lesions: results from the Human Identified Skeletal Collection from the Museu Bocage (Lisbon, Portugal). American Journal of Physical Anthropology, 130(2): 190-200. DOI: 10.1002/ajpa.20309

Mays, S. (2008): Septal aperture of the humerus in a mediaeval human skeletal population. American Journal of Physical Anthropology, 136(4): 432-440. DOI: 10.1002/ajpa.20826

Mays, S., Taylor, G.M. (2003): A first prehistoric case of tuberculosis from Britain. International Journal of Osteoarchaeology, 13(4): 189-196. DOI: 10.1002/oa.671

Mays, S., Taylor, G., Legge, A., Young, D., Turner-Walker, G. (2001): Paleopathological and biomolecular study of tuberculosis in a medieval skeletal collection from England. American Journal of Physical Anthropology, 114(4): 298-311. DOI: 10.1002/ajpa.1042

Meindl, R.S., Lovejoy, C.O. (1985): Ectocranial suture closure: A revised method for the determination of skeletal age at death based on the lateral-anterior sutures. American Journal of Physical Anthropology, 67: 51-63. DOI: 10.1002/ajpa.1330680106

Miles, A.E.W. (1963): The dentition in the assessment of individual age in skeletal material. In: Brothwell, D.R. (Ed.) Dental Anthropology. Oxford University Press, Oxford. pp. 191-209.

Mutolo, M.J., Jenny, L.L., Buszek, A.R., Fenton, T.W., Foran, D.R. (2012): Osteological and molecular identification of brucellosis in ancient Butrint, Albania. American Journal of Physical Anthropology, 147: 254-263. DOI: 10.1002/ajpa.21643

Nemeskéri, J., Harsányi, L., Acsádi, Gy. (1960): Methoden zur Diagnose des Lebensalters von Skelettfunden. Anthropologischer Anzeiger, 24: 70-95.

Nicklisch, N., Maixner, F., Ganslmeier, R., Friederich, S., Dresely, V., Meller, H., Zink, A.R., Alt, K.W. (2012): Rib lesions in skeletons from early Neolithic sites in central Germany: on the trail o f tuberculosis at the onset of agriculture. American Journal of Physical Anthropology, 149(3): 391-404. DOI: 10.1002/ajpa.22137 
Nuorala, E., Götherström, A., Ahlström, T., Donoghue, H.D., Spigelman, M., Lidén, K. (2004): MTB complex DNA in a Scandinavian Neolithic passage grave. In: Molecular Palaeopathology. Ancient DNA analyses of the bacterial diseases tuberculosis and leprosy. Archaeological Research Laboratory, Stockholm.

Ortner, D.J. (1979): Disease and mortality in the Early Bronze Bab-edh-Dhra, Jordan. American Journal Physical Anthropology, 51: 589-597. DOI: 10.1002/ajpa.1330510411

Ortner, D.J. (1999): Paleopathology: Implications for the history and evolution of tuberculosis. In: Pálfi, Gy., Dutour, O., Deák, J., Hutás, I. (Eds) Tuberculosis: Past and Present. Golden Book Publishers and Tuberculosis Foundation, Budapest - Szeged. pp. 253-261.

Ortner, D.J. (2003): Identification of Pathological Conditions in Human Skeletal Remains. Second Edition. Academic Press, San Diego.

Pálfi, Gy. (2002): Paleoepidemiological reconstruction of tuberculosis, with particular attention to Europe. In: Bennike, P., Bodzsár, É.B., Susanne, C. (Eds) Ecological Aspects of Past Human Settlements in Europe. Biennial Books of EAA, 2: 193-210.

Pálfi, Gy., Dutour, O., Deák, J., Hutás, I. (1999, Eds): Tuberculosis: Past and Present. Golden Book Publishers and Tuberculosis Foundation, Budapest - Szeged.

Pálfi, Gy., Ortner, D.J., Dutour, O. (2011): Szkeletális tuberkulózis változatos megjelenési formái juvenilis korú egyéneknél (Terry Anatomical Collection, Washington, D.C., USA). Anthropologiai Közlemények, 52: 17-31.

Perizonius, W.R.K. (1981): Diachronic dental research on human skeletal remains excavated in the Netherlands. I. Bericht. Rijksdienst voor het Oudheidkundig Bodemaderzoek, 31: 369-413.

Pósa, A., Maixner, F., Mende, B.G., Köhler, K., Osztás, A., Sola, C, Dutour, O., Masson, M. Molnár, E., Pálfi, Gy., Zink, A. (2015): Tuberculosis in Late Neolithic-Early-Copper Age human skeletal remains from Hungary. Tuberculosis, 95: S18-S22. DOI: 10.1016/j.tube.2015.02.011

Resnick, D., Niwayama, G. (1988): Diagnose of bone and joint disorders. Saunders. Philadelphia.

Sager, Ph., Schalimtzek, M., Möller-Christensen, V. (1972): A case of spondylitis tuberculosa in the Danish Neolithic age. Danish Medical Bulletin, 19: 176-180.

Santos, A.L., Roberts, C.A. (2001): A picture of tuberculosis in young Portuguese people in the early 20th century: a multidisciplinary study of the skeletal and historical evidence. American Journal of Physical Anthropology, 115(1): 38-49. DOI: 10.1002/ajpa.1054

Schultz, M. (1999): The role of tuberculosis in infancy and childhood in prehistoric and historic populations. In: Pálfi, Gy., Dutour, O., Deák, J., Hutás, I. (Eds) Tuberculosis. Past and Present. Golden Book Publishers, Tuberculosis Foundation, Budapest - Szeged. pp. 503-507.

Schour, J., Massler, M. (1941): The Development of the Human Dentition. Journal of the American Dental Association, 28: 1153-1160.

Spekker, O., Pósa, A., Pálfi, Gy., Zink, A., Maixner, F., Bereczki, Zs., Molnár, E. (2013): Specifikus fertőző megbetegedés diagnózisa Vésztő Mágori-Halom újkőkori leletein. Anthropologiai Közlemények, 54: 77-92.

Steinbock, R.T. (1976): Paleopathological Diagnosis and Interpretation. Charles C. Thomas Publisher, Springfield, Illinois.

Stloukal, M., Hanáková, H. (1978): Die Lange der Langsknochen altslawischer Bevölkerungen unter besonderer Berücksichtigung von Wachstumsfragen. Homo, 29: 53-69.

Strouhal, E. (1987): La tuberculose vertébrale en Egypte et Nubie anciennes. Bulletins et Memoires de la Societe d' Anthropologie de Paris, 14(4): 261-271.

Todd, T.W. (1920): Age changes in the pubis bone: I. The male white pubis. American Journal of Physical Anthropology, 3: 285-334. DOI: 10.1002/ajpa.1330030301

Ubelaker, D.H. (1989): Human Skeletal Remains. Excavation, Analysis, Interpretation. Washington.

Wright, S. (2016): The Long and Complicated Relationship between Humans and Infectious Diseases. The University of Texas at Austin. https://www.academia.edu/25800027/ The_Long_and_Complicated_Relationship_Between_Infectious_Diseases_and_Humans 
Zias, J. (1998): Tuberculosis and the Jews in the ancient Near East: the biocultural interaction. In: Greenblatt, C.L. (Ed.) Digging for Pathogens. Ancient Emerging Diseases - Their Evolutionary, Anthropological and Archaeological Context. Balaban Publisher, Rehovot. pp. 277-297.

Levelezési cím: Mailing address:
Köhler Kitti

Magyar Tudományos Akadémia, Bölcsészettudományi Kutatóközpont Régészeti Intézet

Úri u. 49.

H-1014 Budapest

Hungary

kohler.kitti@btk.mta.hu 